\title{
KINERJA PEMELIHARAAN JALAN KABUPATEN PADA DINAS BINA MARGA DAN PENGAIRAN KABUPATEN SUBANG
}

\author{
Iwan Henri Kusnadi dan Luki Natika \\ Dosen Program Studi Administrasi Publik Fakultas Ilmu Administrasi \\ Universitas Subang \\ E-mail: ; iwanhenrikusnadi@ymail.com \& luki_natika@yahoo.com
}

\begin{abstract}
ABSTRAK
Tujuan dilakukannya penulisan adalah untuk mengetahui Kinerja Pemeliharaan Jalan Kabupaten Pada Dina Bina Marga dan Pengairan Kabupaten Subang, selain itu untuk mengetahui faktor-faktor yang menjadi hambatan dalam Kinerja Pemeliharaan Jalan Kabupaten Pada Dinas Bina Marga dan Pengairan Kabupaten Subang.

Objek yang menjadi penelitian adalah Pada Dinas Bina Marga dan Pengairan Kabupaten Subang, yang beralamat di Jalan K.S. Tubun No.16 Kabupaten Subang. Telepon (0260) 411106 Subang. Berdasarkan hasil penelitian menemukan beberapa masalah / hambatan sebagai berikut : masih terdapatnya kegiatan pekerjaan pemeliharaan jalan yang hasilnya kurang optimal sehingga menyebabkan jalan yang berlubang mudah rusak kembali dan masih ditemukan adanya kerusakan jalan yang berlubang dalam pemeliharaan jalan, melihat dari hambatan tersebut maka penulis menjadikan Dinas Bina Marga sebagai objek penelitian.

Metode yang digunakan dalam penelitian ini adalah menggunakan analisis kualitatif dengan teknik pengambilan sampel adalah Purposive Sampling yaitu jenis sampel yang pemilihannya didasarkan atas kriteria tujuan dan manfaatnya. Informan yang diambil adalah Kasie Pemeliharaan, Kabid Bina Marga, Kasie penyususunan program Bina Marga dan Masyarakat. Teknik pengumpulan data meliputi wawancara dan observasi.

Berdasarakan hasil penelitian, diperoleh hasil bahwa Kinerja Pemeliharaan Jalan Kabupaten pada Dinas Bina Marga dan pengairan Kabupaten Subang dalam pengerjaanya belum sepenuhnya memperhatikan faktor- faktor kinerja sehingga dalam pemeliharaan jalan kabupaten belum efektif karena hasil yang diinginkan yaitu kondisi jalan yang baik, pengerjaannya sesuai dengan rencana dan target waktu yang ditentukan belum sepenuhnya tercapai dalam Pemeliharaan Jalan Kabupaten.
\end{abstract}

\section{Kata Kunci : Kinerja}

\section{PENDAHULUAN}

Sebagai salah satu prasarana perhubungan dalam kehidupan bangsa, kedudukan dan peranan jaringan jalan pada hakikatnya menyangkut hajat hidup orang banyak serta mengendalikan struktur pengembangan wilayah pada tingkat nasional, terutama yang menyangkut perwujudan perkembangan hasil-hasil pembangunan, serta peningkatan pertahanan dan keamanan negara, dalam rangka mewujudkan sasaran-sasaran pembangunan nasional menuju masyarakat Indonesia yang adil dan makmur berdasarkan pancasila.
Dalam Pasal 5 ayat 2 Undang-undang Republik Indonesia Nomor 38 Tahun 2004 tentang Jalan, disebutkan bahwa jalan mempunyai peranan penting dalam bidang ekonomi, sosial budaya, lingkungan hidup, politik, pertahanan dan keamanan, serta dipergunakan untuk sebesar-besar kemakmuran rakyat. Jalan sebagai prasarana distribusi barang dan jasa merupakan urat nadi kehidupan masyarakat, bangsa, dan Negara sehin,gga akan mendorong pengembangan semua sarana wilayah, pengembangan dalam usaha mencapai tingkat perkembangan antar daerah yang semakin merata. Artinya infrastruktur jalan 
merupakan urat nadi perekonomian suatu wilayah, hal ini disebabkan perannya dalam menghubungkan serta meningkatkan pergerakan manusia, dan barang.

Berdasarakan hal tersebut dapat dikatakan bahwa jalan sebagai sistem transportasi nasional mempunyai peranan penting terutama dalam mendukung bidang ekonomi, sosial dan budaya serta lingkungan dan dikembangkan melalui pendekatan pengembangan wilayah agar tercapai keseimbangan dan pemerataan pembangunan antar daerah, membentuk memperkukuh kesatuan nasional untuk memantapkan pertahanan dan keamanan nasional.

Serta membentuk struktur ruang dalam rangka mewujudkan sarana pembangunan nasional yang aman, nyaman, dan berdaya guna benar-benar akan dirasakan manfaatnya oleh masyarakat.

Peraturan pemerintah Nomor 34 Tahun 2006 tentang jalan, yang tertuang di pasal 96-101 menjelaskan tentang pengoperasian dan pemeliharaan jalan. Disini di jelaskan Penyelenggara jalan mempunyai kewajiban dan tanggungjawab untuk memelihara jalan sesuai dengan kewenangannya. Pemeliharaan jalan merupakan prioritas tertinggi dari semua jenis penanganan jalan. Pemeliharaan jalan meliputi pemeliharaan rutin, pemeliharaan berkala, dan rehabilitasi. Pemeliharaan jalan dilaksanakan berdasarkan rencana pemeliharaan jalan. karena tujuan pemeliharaan jalan adalah untuk mempertahankan kondisi jalan mantap sesuai dengan tingkat pelayanan dan kemampuannya pada saat jalan tersebut selesai dibangun dan dioperasikan sampai dengan tercapainya umur rencana yang telah ditentukan.

Kewenangan pengelolaan jalan terbagi ke dalam 2 (dua) kelompok, yaitu pemerintah pusat dan pemerintah daerah. Pemerintah pusat memiliki kewenangan dalam pengelolaan sistim jaringan jalan perimer berupa jalan nasional dan jalan propinsi, sedangkan pemerintah daerah memiliki kewenangan pengelolaan sistim jaringan jalan sekunder berupa jalan kabupaten/kota. Dalam Undang-Undang Republik Indonesia Nomor 32 Tahun 2004 Tentang Pemerintahan Daerah, menjelaskan bahwa Urusan wajib yang menjadi kewenangan pemerintahan daerah untuk kabupaten/kota merupakan urusan yang berskala kabupaten/kota diantaranya pemeliharaan jalan Kabupaten.

Khusus untuk pemerintah Kabupaten, negara memberikan wewenang penyelenggaraan jalan meliputi pemeliharaan jalan Kabupaten dan jalan Desa. Selanjutnya sesuai dengan sistem pemerintahan yang berlaku di Indonesia wewenang tersebut dilimpahkan kepada instansi yang ditunjuk di daerah. Wewenang tentang jalan tersebut meliputi kegiatan-kegiatan yang meliputi seluruh siklus kegiatan dan perwujudan jalan yang meliputi pengaturan, pembinaan, pembangunan dan pengawasan jalan.

Dinas Bina Marga dan Pengairan Kabupaten Subang selaku kepanjang tangan Pemerintah Kabupaten Subang yang mempunyai misi Membangun dan memelihara hasil-hasil pembangunan secara baik dan berkesinambungan, dengan melaksanakan pembangunan dan pemeliharaan jalan dengan maksud meningkatkan pelayanan yang sesuai dengan pertumbuhan lalu lintas dengan kemampuan yang mantap, melalui pemeliharaan jalan yang alokasi dananya berasal dari Anggaran Pendapatan Dan Belanja Negara (APBN) dan dari Anggaran Pendapatan dan Belanja Daerah (APBD).

Dalam pelaksanaan pemeliharaan jalan pada dinas bina marga dan pengairan kabupaten subang diperlukan adanya pemantauan secara terus menerus melihat perkembanganya yang tujuanya adalah untuk mengetahui seberapa jauh kinerja dalam pemeliharaan jalan tersebut telah dilaksanakan dan bagaimana hasilnya diukur dengan sasaran yang hendak dicapai, sehingga hasil pemantauan tersebut dapat diambil langkahlangkah agar perlaksanaan pemeliharaan jalan selanjutnya menunjang dan tidak merugikan upaya tugas pokok selanjutnya.

Kinerja berfungsi untuk mengukur secara kualitas dan kuantitas yang dicapai oleh suatu organisasi dalam melaksanakan tugas nya sesuai dengan tanggung jawab yang diberikan kepadanya. Berdasarkan hasil penelitian yang dilakukan pada Dinas Bina Marga dan pengairan kabupaten subang, diperoleh beberapa permasalahan sebagai berikut:

Masih terdapatnya kegiatan pekerjaan pemeliharaan jalan yang dalam pelaksanaanya kurang Optimal menyebabkan jalan yang berlubang mudah rusak kembali. Masih ditemukan adanya kerusakan-kerusakan jalan yang berlubang dalam pemeliharaan jalan pada Dinas Bina Marga dan Pengairan Kabupaten Subang. Dengan kondisi jalan sebagai berikut :Ruas Jalan purwadadiRuas jalan cijambe Ruas jalan Arif rahman Hakim.

Berdasarkan uraian latar belakang, maka penulis tertarik untuk mengadakan penelitian untuk dikaji secara lebih mendalam dalam bentuk karya ilmiah.

\section{RUMUSAN MASALAH}

Berdasarkan latar belakang yang diuraikan di atas, permasalahan akan dibahas dalam 
penelitian berfokus pada kinerja dalam pemeliharaan jalan. Secara rinci, fokus masalah tersebut dirumuskan dalam beberapa pertanyaan penelitian sebagai berikut :

1. Bagaimana kinerja pemeliharaan jalan pada Dinas Bina Marga Dan Pengairan Kabupaten Subang?

2. Faktor-Faktor apa saja yang menjadi Hambatan dalam kinerja pemeliharaan jalan pada Dinas Bina Marga Dan Pengairan Kabupaten Subang?

\section{KERANGKA PEMIKIRAN}

Berdasarkan Rumusan masalah yang telah dikemukakan sebelumnya menurut peneliti, maka untuk memberikan pemecahan masalah tersebut perlu adanya pedoman sebagai kerangka pemikiran penelitian dengan mengacu kepada pendapat para ahli antara lain menurut Fahmi (2007: 27) menyatakan bahwa kinerja adalah gambaran mengenai tingkat pencapaian pelaksanaan suatu kegiatan / program / kebijaksanaan dalam mewujudkan sasaran, tujuan, misi, dan visi organisasi yang tertuang dalam perumusan skema strategis suatu organisasi.

Berdasarkan pendapat tersebut diatas dapat penulis kemukakan bahwa kinerja merupakan suatu kegiatan sejauh mana tingkat pencapaian kinerja pegawai dalam menyelesaikan pekerjaan sesuai dengan target waktu yang telah ditetapkan untuk mewujudkan kinerja yang lebih baik maka kinerja memegang peranan penting.

Oleh karena itu dalam pelaksanaanya harus memperhatikan faktor-faktor kinerja menurut kumorotomo dalam pasolong (1999 : 180) adalah sebagai berikut:

1. Efisiensi

Efisiensi menyangkut pertimbangan tentang keberhasilan organisasi pelayanan public mendapatkan laba memanfaatkan faktorfaktor produksi serta pertimbangan yang berasal dari rasionalitas ekonomis.

2. Efektivitas,

Apakah tujuan dari didirikannya organisasi pelayanan public tersebut tercapai? Hal tersebut erat kaitannya organisasi rasionalitas teknis, nilai, misi, tujuan organisasi serta fungsi agen pembangunan.

3. Keadilan

Keadilan mempertanyakan distribusi dan alokasi layanan yang diselenggarakan oleh organisasi pelayanan publik
4. Daya tanggap.

Berlainan dengan bisnis yang dilaksanakan oleh perusahaan swasta ,organisasi pelayanan public merupakan bagian dari daya tanggap Negara atau pemerintah akan kebutuhan masyarakat yang mendesak.Oleh sebab itu, criteria organisasi tersebut secara keseluruhan harus dapat dipertanggungjawabkan secara transparan demi memenuhi kriteria daya tanggap.

Dengan memperhatikan faktor-faktor kinerja tersebut maka jelaslah seorang pimpinan memperhatikan kinerja pegawai harus lah berpedoman kepada faktor-faktor dimaksud sehingga kinerja yang dilaksanakan oleh pimpinan terselenggara dengan baik sehingga dapat menunjang terhadap terwujudnya keberhasilan dalam kinerja pemeliharaan jalan pada dinas Bina Marga dan pengairan kabupaten subang dan pada akhirnya tujuan organisasi dapat dicapai secara efektif mencapai target yang diharapkan dengan meningkatkan kinerja maka dapat menentukan keberhasilan suatu pemeliharaan jalan yang komperhensif yang meliputi pengukuran bidang tertentu dimana tujuan dari pelaksanaan pemeliharaan jalan dapat tercapai dengan baik.

Berdasarkan kesimpulan diatas maka penulis membuat kerangka pemikiran gambar 2.1 sebagai berikut :

\section{Gambar \\ Kerangka Pemikiran}

Pemeliharaan Jalan Kabupaten Pada Dinas Bina Marga Dan Pengairan Kabupaten Subang

Menurut kumorotomo dalam pasolong (1999:180)

dalam mengukur kinerja antara lain :

1. Efisiensi

2. Efektivitas

3. Keadilan

4. Daya tanggap

Kinerja dalam Pemeliharaan Jalan Pada Dinas Bina Marga Dan Pengairan Kabupaten Subang Tercapai / Tidak Tecapai 


\section{HIPOTESIS}

Berdasarkan kerangka pemikiran diatas, maka dalam penelitian ini penulis mengajukan hipotesis sebagai berikut : Kinerja Pemeliharaan Jalan Kabupaten Pada Dinas Bina Marga Dan Pengairan Kabupaten Subang yang akan berhasil bilaman ditentukan oleh Efisiensi, Efektivitas, Keadilan, Daya Tanggap.

\section{METODE PENELITIAN}

Penelitian ini menggunakan pendekatan kualitaif. Sedangkan informan yang akan ditemui sebagai sumber informasi yang mengetahui tentang kinerja pemeliharaan jalan Pada Dinas Bina Marga Dan Pengairan Kabupaten Subang, adalah para pegawai yang melaksanakan pemerliharaann jalan dan masyarakat pengguna jalan tersebut.

\section{PEMBAHASAN}

\section{Kinerja Pemeliharaan Jalan Kabupaten Pada Dinas Bina Marga Dan Pengairan Kabupaten Subang.}

infrastruktur jalan yang baik serta lancar untuk dilalui penting perannya dalam mengalirkan pergerakan komoditas yang selanjutnya akan mampu menggerakkan perkembangan kehidupan sosial dan meningkatkan kemampuan ekonomi masyarakat. Kondisi jalan yang lancar merupakan ukuran yang dapat menggambarkan baik buruknya operasional lalu lintas berupa kecepatan, waktu tempuh (efisiensi waktu), kenyamanan, pandangan bebas, keamanan dan keselamatan jalan yang paling utama.

Untuk menjaga pembangunan yang dinamis serta menjungjung pembangunan ekonomi yang lebih maju, maka perlu dilakukan penanganan infrastruktur jalan yang meliputi pembangunan jalan, peningkatan jalan dan pemeliharaan jalan. penanganan tersebut ditujukan untuk menjaga kondisi jalan dalam keadaan lancar dan mantap. Pemeliharaan jalan perlu dilakukan secara terus menerus/rutin aga keadaan jalan semakin baik

Pemeliharan jalan dalam kewenangan pengelolaannya terbagi ke dalam 2 (dua) kelompok, yaitu pemerintah pusat dan pemerintah daerah. Pemerintah pusat memiliki kewenangan dalam pengelolaan sistim jaringan jalan perimer berupa jalan nasional dan jalan propinsi, sedangkan pemerintah daerah memiliki kewenangan pengelolaan sistim jaringan jalan sekunder berupa jalan kabupaten/kota.

Wewenang pengelolaan jaringan jalan dapat dikelompokkan menurut:
1. Jalan Nasional adalah Menteri Pekerjaan Umum (dulu Menteri Kimpraswil) atau pejabat yang ditunjuk;

2. Jalan Propinsi adalah Pemerintah Daerah atau instansi yang ditunjuk;

3. Jalan Kabupaten adalah Pemerintah Daerah Kabupaten atau instansi yang ditunjuk;

4. Jalan Kota adalah Pemerintah Daerah Kota atau instansi yang ditunjuk;

5. Jalan Desa adalah Pemerintah Desa/Kelurahan;

6. Jalan Khusus adalah pejabat atau orang yang ditunjuk.

Wilayah Kabupaten Subang memiliki prasarana jalan yang memadai yang terdiri dari jalan negara, jalan provinsi, jalan kecamatan dan jalan desa. Panjang jalan kabupaten sampai saat ini sekitar 1.054,50 Km, panjang jalan provinsi $134,123 \mathrm{Km}$ dan jalan negara 57,42 Km. Dengan demikian luasnya wilayah Kabupaten Subang dituntut harus memiliki jalan yang bagus demi terciptanya pelayanan yang prima terhadap masyarakat.

Dinas Bina Marga dan Pengairan Kabupaten Subang selaku kepanjang tangan Pemerintah Kabupaten Subang yang mempunyai tugas pokok melakukan pengurusan dan pengelolaan jalan Kabupaten yang berada di wilayah Kabupaten Subang, dalam melaksanakan program di bidang pekerjaan umum dan perhubungan dengan maksud meningkatkan pelayanan yang sesuai dengan pertumbuhan lalu lintas dengan kemampuan yang mantap, melalui dengan meingkatkan kinerja pemeliharaan jalan.

Dalam pemeliharaan jalan pada Dinas Bina Marga dan Pengairan Kabupaten Subang diperlukan adanya pemantauan secara terus menerus dan perkembangan yang tujuanya adalah untuk mengetahui seberapa jauh kinerja pemeliharaan jalan tersebut telah dilaksanakan dan bagaimana hasilnya diukur dengan sasaran yang akan dicapai dengan memperhatikan faktor kinerjanya harus lebih di tingkatkan agar mendapat hasil yang maksimal selanjutnya hal tersebut sesuai dengan pendapat(Mahsun, 2006 :25) sebagai berikut :

"Kinerja adalah gambaran mengenai tingkat pencapaian pelaksanaan suatu kegiatan/program/kebijakan dalam mewujudkan sasaran, tujuan, misi, dan visi organisasi yang tertuang dalam strategic planning suatu organisasi

Berdasarkan definisi diatas penulis menyimpulkan bahwa kinerja merupakan konsep 
yang digunakan oleh suatu organisasi untuk menilai seberapa besar hasil yang telah dicapai dan proses pekerjaannya untuk mencapai tujuan organisasi dalam pelaksanaan kegiatan, program, kebijaksanaan guna mewujudkan visi, misi, dan tujuan organisasi yang telah ditetapkan sebelumnya.

Kinerja merupakan hasil kerja oleh pegawai atau aparatur dinas bina marga dalam menjalankan tugasnya sesuai dengan wewenang masing-masing yang bisa dipertanggung jawabkan dan dilaksanakan sesuai prosedur dan perundangundangan dengan tujuan untuk mencapai suatu organisasi.

Kinerja dapat menentukan suatu keberhasilan dalam melaksanakan kegiatan yang telah dijalankan dengan pemeliharaan jalan Kabupaten pada Dinas Bina Marga dan Pengairan Kabupaten Subang. Dengan meningkatkan kinerja yang lebih baik maka hasil dari kegiatan akan sesuai dengan rencana atau program yang telah ditentukan sebelumnya yang pada akhirnya akan tercapai efisiensi dan efektivitas pelaksanaan pemeliharaan jalan baik ditinjau dari segi proses waktu maupau hasil dari pekerjaan.

Dalam pemeliharaan jalan harus memperhatikan beberapa faktor menurut kumorotomo dalam pasolong (1999:180) adalah sebagai berikut :

\section{Efisiensi \\ 2. Efektivitas \\ 3. Keadilan \\ 4. Daya tanggap}

Dengan memperhatikan faktor -faktor kinerja tersebut maka jelaslah seorang pemimpin memperhatikan kinerja pegawai harus lah berpedoman kepada faktor-faktor dimaksud agar dapat meningkatkan kinerja yang lebih baik sehingga dapat menunjang terhadap terwujudnya keberhasilan pemeliharaan jalan pada Dinas bina Marga dan Pengairan kabupaten Subang dan pada akhirnya tujuan organisasi dapat di capai secara efektif dengan meningkatkan kinerja maka dapat menentukan keberhasilan suatu pemeliharaan jalan yang komperhensiif yang meliputi pengukuran bidang tertentu dimana tujuan dari pemeliharaan jalan dapat tercapai dengan baik.

Kinerja ini sangat penting dilakukan karena hal ini dapat digunakan sebagai ukuran keberhasilan suatu organisasi dalam mencapai misinya. Untuk organisasi pelayanan publik, informasi mengenai kinerja tentu sangat berguna untuk menilai seberapa jauh kinerja yang diberikan oleh organisasi itu memenuhi harapan dan memuaskan pengguna jasa. Namun sayangnya, penilaian kinerja birokrasi publik masih amat jarang dilakukan. Berbeda dengan organisasi bisnis yang kinerjanya dengan mudah bisa dilihat dari profitabilitas, yang diantaranya tercermin dari indeks harga saham di bursa, birokrasi publik tidak memiliki tolak ukur yang jelas dan tidak mudah diperoleh informasinya oleh publik. Selain itu, kinerja dapat digunakan untuk mengukur tingkat prestasi atau keberhasilan individu maupun kelompok individu.

Pemeliharaan jalan sangatlah penting karena sebagus apapun jalan kalau tidak ada pemeliharaan maka akan cepat rusak, dalam hal jenis peralatan/perlengkapan yang digunakan dalam pekerjaan pemeliharaan jalan, umumnya merupakan peralatan dan perlengkapan yang sederhana dan mudah mengoperasikannya. Bahan/material yang perlu disediakan tidak dalam jumlah yang besar. Metode pelaksanaan yang diterapkan umumnya tidak rumit atau sederhana. Sehubungan dengan itu, biaya yang disediakan umumnya relatif kecil dan bahkan kurang sesuai/memadai, atau terlupakan/terabaikan. Bertitik tolak dari kondisi tersebut, harapan untuk mendapatkan hasil kerja yang optimal akan sulit dicapai.

Dinas Bina Marga dan Pengairan Kabupaten Subang sebagai instansi pemerintah yang ditunjuk untuk melaksanakan pemeliharaan jalan diharapkan dapat melaksanakan tugasnya dengan baik karena sesuai dengan Visi dan Misi Dinas Bina Marga Dan Pengairan Kabupaten Subang yaitu Membangun dan memelihara hasilhasil pembangunan secara baik dan berkesinambungan. Agar visi dan misi terlaksana dengan baik Dinas Bina Marga dan Pengairan Kabupaten Subang merupakan salah satu unsur pelaksana Pemerintah Daerah Kabupaten Subang yang mempunyai tugas pokok melaksanakan sebagian unsur rumah tangga dibidang kebinamargaan yakni melaksanakan pengendalian operasional, pembangunan, pemeliharaan jalan dan jembatan yang berstatus jalan negara, jalan provinsi dan jalan kabupaten yang ada di wilayah kerja Kabupaten Subang.

Dalam melaksanakan tugas pokok tersebut dalam pemeliharaan jalan kabupaten. Dari hasil pengamatan penulis dapat dikemukakan bahwa dalam upaya mewujudkan efektivitas pelaksanaan pemeliharaan kinerja Kepala Dinas Bina Marga dan Pengairan Kabupaten Subang. 


\section{Efisiensi}

Efisiensi adalah suatu pertimbangan tentang keberhasilan organisasi pelayanan public mendapatkan laba memanfaatkan faktor-faktor produksi serta pertimbangan yang berasal dari rasionalitas ekonomis. ( Kumorotomo dalam pasolong 1999:180 ). Efiiensi penggunaan sumber daya secara minimum guna pencapaian hasil yang optimum, efisiensi menganggap bahwa tujuantujuan yang benar telah ditentukan dan berusaha untuk mencari cara-cara yang paling baik untuk mencapai tujuan tersebut, Efisiensi merupakan suatu ukuran dalam membandingkan rencana penggunaan masukan dengan penggunaan yang telah direalisasikan dalam pengerjaan pemeliharaan jalan tingkat efisiensi nya di perhatikan oleh pegawai atau tidaknya dilihat dari hasil akhir pengerjaan pemeliharaan jalan kabupaten dinas bina marga dan pengairan kabupaten subang, apabila dilihat dari hasil penelitian dalam pengerjaan pemeliharaan jalan dirasakan masih kurang baik sehingga dalam pengerjaan tidak sesuai dengan waktu yang di tetapkan karena pegawainya kurang memperhatikan tingkat efisiensinya.

Bila kita perhatikan lebih detail sebenarnya dalam pemeliharaa jalan dinilai dari segi kinerjanya kurang diperhatikan oleh pegawai mengakibatkan masih adanya jalan yang belubang. Bedasarkan penelitian dilapangan masih ditemukan kondisi jalan yang berlubang sebagai berikut :

1. Ruas jalan Purwadadi

2. Ruas jalan Cijambe

3. Ruas jalan Arif rahman hakim

Berdasarkan kondisi jalan sebagai berikut maka pengguna jalan menjadi terganggu akibat jalan yang berlubang. Pengguna jalan menjadi terganggu karena masih ada jalan yang berlubang dan belum ada perbaikan jalan. Karena tujuan dari pemeliharaan jalan adalah untuk mempertahankan kondisi jalan mantap sesuai dengan tingkat kemampuannya

Dinas Bina Marga dan Pengairan Kabupaten Subang, harus memperhatikan tentang ruas jalan yang rusak dan segera memperbaikinya sebelum terjadi kerusakan secara total, dan yang paling penting tidak ada korban pengguna jalan yang terjadi kecelakaan lagi akibat jalan yang berlubang. Dengan kata lain, Kinerja pemeliharaan jalan faktor efisiensinya kurang diperhatikan sehingga mengakibatkan dalam pengerjaan pemeliharaan jalan tidak sesuai dengan waktu yang ditetapkan.

\section{Efektivitas}

Efektivitas adalah suatu pencapaian tujuan secara tepat atau memilih tujuan - tujuan yang tepat dari serangkaian alternatif atau pilihan cara dan menentukan pilihan dari beberapa pilihan lainya. (Afdinizar 2003;326). Efektivitas bisa juga diartikan sebagai pengukuran keberhasilan dalam pencapaian tujuan -tujuan yang telah ditentukan ,efektivitas merupakan akhir dari kegiatan pengerjaan pemeliharaan jalan tingkat efektivitas nya bisa dilihat dari akhir hasil pengerjaan pemeliharaan jalan kabupaten pada dinas bina marga dan pengairan kabupaten subang apabila dilihat dari hasil penelitian dalam pengerjaan pemeliharaan jalan masih dirasakan kurang optimal dilihat dari hasil pekerjaan ,seperti menambal jalan yang berlubang tidak bisa bertahan lama sehingga hasil penambalan cepat rusak kembali diakibatkan karena kurang bahan dan efektivitasnya kurang ditingkatkan dalam pengerjaan jalan.

Bila kita perhatikan sebenarnya dalam pemeliharaa jalan dinilai dari segi kinerjanya masih kurang diperhatikan oleh pegawai karena dilihat dari hasilnya dalam pengerjaan pemeliharaan jalan masih belum mencapai tujuan yang di inginkan oleh para pengguna jalan.

Dinas Bina Marga dan pengairan Kabupaten Subang masih dirasakan kurang memperhatikan kualitas kinerjanya dan kurang memperhatikan ruas jalan yang berlubang. dapat menyimpulkan bahwa dalam kinerja pemeliharaan jalan faktor efektivitasnya kurang diperhatikan akibatnya jalan mudah rusak kembali.

\section{Keadilan}

Keadilan mempertanyakan distribusi dan alokasi layanan yang diselenggarakan oleh organisasi pelayanan publik. (Priyono, 1993: 35) Keadilan memberikan sesuatu kepada setiap anggota masyarakat sesuai dengan haknya yang harus diperolehnya tanpa diminta; tidak berat sebelah atau tidak memihak kepada salah satu pihak; mengetahui hak dan kewajiban, mengerti mana yang benar dan mana yang salah, bertindak jujur dan tetap menurut peraturan yang telah ditetapkan. Dalam pemeliharaan jalan harus dilakukan secara merata dan tidak pilih kasih dalam pengerjaan pemeliharaan jalan tersebut, berdasarkan penelitian bahwa dalam pengerjaan pemeliharaan jalan dilaksanakan secara tidak 
merata yang lebih diutamakan hanya ke jalan pejabat tertntu padahal ruas jalan yang rusak total belum saja diperbaiki . pengerjaan pemeliharaan jalan dilakukan secara adil dan tidak pilih kasih serta merata dalam pemeliharan jalannya

Bila kita pehatikan bahwa dalam pengerjaan pemeliharaan jalan dapat dilihat dari segi keadilan nya masih dirasakan belum secara merata. Dinas Bina Marga dan Pengairan Kabupaten Subang bisa bersikap adil dalam pemeliharaan jalan tidak hanya jalan pejabat saja yang diperhatikan atau di perbaiki tapi jalan yang lain juga masih banyak yang lebih rusak dan harus segera di perbaiki “. Dinas Bina Marga dan Pengairan Kabupaten Subang masih dirasakan belum bisa bersikap adil dalam pengerjaan pemeliharaan jalan sehingga mengakibatkan kecemburuan sosial di tengah masyarakat. Dengan kata lain, bahwa kinerja dalam pemeliharaan jalan dari faktor keadilannya belum diperhatikan sehingga masyarakat/ pengguna jalan belum merasakan keadilan dalam pengerjaan pemeliharaan jalan.

\section{Daya Tanggap}

Organisasi pelayanan publik merupakan bagian dari daya tanggap Negara atau pemerintah akan kebutuhan masyarakat. ( Kumorotomo dalam Pasolong 1999;180 ).,Oleh sebab itu, criteria organisasi tersebut secara keseluruhan harus dapat dipertanggungjawabkan secara transparan demi memenuhi kriteria daya tanggap. Organisasi pelayanan publik merupakan bagian dari daya tanggap dalam setiap hal yang menjadi keluhan masyarakat, harus dapat dipertanggungjawbkan secara transparan dalam setiap yang menjadi keluhan masyarakat apa ditanggapi dengan baik oleh dinas bina marga dan pen gairan kabupaten subang tentang setiap keluhan masalah kondisi jalan yang rusak, apabila dilihat dari hasil penelitian dalam setiap keluhan masyarakat ditanggapi dengan baik tapi dalam pengerjaan pemeliharaan jalan tidak tepat waktu.

bahwa untuk meningkatkan pelayanan terhadap masyarakat, Dinas Bina Marga dan Pengairan Kabupaten Subang dalam menentukan usulan kegiatan pemeliharaan jalan harusnya disusun berdasarkan peraturan yang telah dibuat agar kegiatan pemeliharaan jalan menjadi tepat sasaran, agar keinginan masyarakat dalam pemeliharaan jalan dapat memperbaiki kondisi jalan sehingga transportasi lalu lintas menjadi lancar.

\section{Faktor - Faktor Yang Menjadi Hambatan Dalam kinerja Pemaliharaan Jalan Kabupaten Pada Dinas Bina Marga Dan Pengairan Kabupaten Subang.}

Berdasarkan hasil penelitian dilapangan terdapat faktor-faktor yang menjadi hambatan dalam kinerja pemeliharaan jalan kabupaten pada Dinas Bina Marga dan Pengairan Kabupaten Subang, sebagai berikut :

1. Responsivitas

Responsivitas merupakan suatu kemampuan organisasi untuk mengenali dan memenuhi kebutuhan masyarakat dengan kemampuan organisasi pemerintah dalam menjalankan misinya sehingga dalam pengerjaan pemeliharaan jalan bisa sesuai dengan waktu yang telah ditetapkan dan mendapatkan hasil yang optimal dalam pemeliharaan jalan.

2. Faktor Volume Kendaraan Volume kendaraan yang terus meningkat juga menjadi faktor penghambat dalam pemeliharaan jalan. volume kendaraan yang terus meningkat mengakibatkan terganggunya pemeliharaan jalan karena dengan meningkatnya volume kendaraan mengakibatkan daya dukung jalan menurun apalagi dengan intonase kendaraan yang melebihi batas sehingga mempercepat kerusakan jalan. Dengan asumsi tidak ada kendaraan yang kelebihan muatan (muatan sumbu terberat melebihi beban sumbu standar), maka umur rencana jalan dapat ditentukan dengan memperkirakan lamanya periode yang diperlukan sampai tercapainya jumlah lintasan beban standar yang direncanakan. Permasalahan terjadi ketika pada tahap perencanaan, beban yang diperhitungkan merupakan beban standar, namun kenyataan yang terjadi di lapangan banyak dijumpai truk-truk dengan muatan sumbu terberat melebihi beban sumbu standar (kelebihan muatan). Sehingga penambahan beban pada truk yang kelebihan muatan akan memberikan peningkatan yang sangat signifikan pada kendaraan dan dapat mempercepat kerusakan jalan sehingga jalan mudah berlubang.

3. Faktor alam Faktor alam merupakan salah satu faktor yang sangat berpengaruh dalam pengerjaan pemeliharaan jalan kabupaten akibat curah hujan menjadikan jalan mudah rusak lagi karena disaat penambalan jalan dilaksanakanya pada musim hujan, sebaiknya apabila akan melakukan penambalan jalan yang berlubang tidak dikerjakan pada saat 
musim ,hujan karena hasilnya pun tidak akan efektif

\section{KESIMPULAN}

Berdasarkan hasil analisis dan pembahasan yang dilakukan dapat ditarik beberapa kesimpulan mengenai kinerja Pemeliharaan Jalan Kabupaten Pada Dinas Bina Marga dan Pengairan.

1. Kinerja pemeliharaan jalan Kabupaten masih belum efektif karena hasil yang diinginkan yaitu kondisi jalan yang baik, pengerjaannya sesuai dengan rencana dan target waktu dan pekerjaanya belum sepenuhnya tercapai. Faktor-faktor yang mempengaruhi Keberhasilan kinerja pemeliharaan jalan kabupaten pada Dinas Bina Marga dan Pengairan adalah efisiensi, efektivitas, keadilan, dan daya tanggap. Dalam Dinas Bina Marga dan Pengairan Kabupaten Subang faktor kinerja yang belum efektif yaitu faktor efisiensi dan efektivitas.

2. Faktor-faktor yang menjadi hambatan dalam pelaksanaan kinerja pemeliharaan jalan pada Dinas Bina Marga dan Pengairan adalah faktor efisiensi, faktor efektivitas dan faktor alam.

\section{REKOMENDASI}

Berdasarkan hasil penelitian seperti diuraikan diatas, kinerja pemeliharaan jalan kabupaten seharusnya lebih memperhatikan tingkat efisiensi nya sehingga berpengaruh dalam kualitas jalan yang ada dikabupaten subang, selain memperhatikan tingkat efisiensi juga harus memperhatikan tingkat efektivitasnya karena sangat berpengaruh dalam pencapaian pemeliharaan jalan yang optimal apabila tingkat efisiensi dn efektivitasnya kurang diperhatikan hasil akhir dari pengerjaan pemeliharan jalan tidak akan mencapai tujuan yang telah ditentukan.

\section{DAFTAR PUSTAKA}

Amstrong, Michael dan angela baron. 1998. Performance management. London : institute of personal and development

Creswell. John. 2010. Reasearch Design pendekatan kualitatif dan kuantitatif, dan mixed . pustaka pelajar: Yogyakarta

Dharma, Agus. 1991. Manajemen Prestasi Kerja. Jakarta: Rajawali Pers.

Fahmi, Irham. 2007. Manajemen Kinerja Teori dan Aplikasi. Bandung: Alfabeta.
Hasibuan, Malayu S.P. 2003.Manajemen Sumber Daya Manusia.Jakarta: Bumi Aksara.

Mahsun , mohamad, 2006. Pengukuran kinerja sektor publik, BPFE Yogyakarta.

Rivai,Veithzal.2004.Manajemen Sumber Daya Manusia untuk Perusahaan. Jakarta: PT.Raja Grafindo Persada.

Simanjuntak,Payaman.2005.Manajemen dan Evaluasi Kinerja, cetakan pertama.Jakarta: Bumi Aksara.

Sedarmayanti.2007.Manajemen Sumber Daya Manusia.Bandung: Refika Aditama.

Sugiyono .2011. metode penelitian Administrasi kualitatif dan kuantitatif $R \& D$. ALFABETA: Bandung

Wibowo 2007. Manajmen kinerja edisi ketiga. Jakarta: rajawali pers

\section{Sumber lain :}

Ditjen,Bina Marga. Dit Bina Tehnik 1995 Manual Pemeliharaan Rutin Untuk Jalan Nasional Dan Jalan Propinsi. Jilid I. Metode Survey. Departemen Pekerjaan Umum

Ditjen.Bina Marga. Dit. Bina Teknik. 1995. Manual Pemeliharaan Rutin Untuk Jalan Nasional Dan Jalan Propinsi. Jilid I. Metode Perbaikan Standar. Departemen Pekerjaan Umum

Undang - undang Republik Indonesia Nomor 38 Tahun 2004 tentang jalan

Peraturan Pemerintah Republik Indonesia Nomor : 34 Tahun 2006 tentang jalan

Peraturan Bupati Subang Nomor : 14 GI tentang Tugas Pokok dan Fungsi Dinas Bina Marga dan Pengairan Kabupaten subang 
